\title{
Women's Role In Informal Sector In Hyderabad
}

\author{
Shazia Shahab Sheikh \\ Department of Media \& Communication Studies \\ University of Sindh
}

\author{
Abida Hafeez \\ Applied Economics Research Center \\ University of Karachi
}

\begin{abstract}
Abdul Hameed Mallah
Women Empowerment Program SAFWCO
\end{abstract}

\begin{abstract}
The aim of the study is to find out how much women are contributing in the household's budget in slum areas of Hyderabad district. A sample comprised of 200 women workers. They were randomly selected in four slum areas in Hyderabad district including: Parytabad, Ghera coloni (Latifabaf unit 9), Haliroad and Qasmabad. A close ended questionnaire technique was used and data was analyzed through SPSS (version 18). The findings show that about $48 \%$ of single status women have more than an average contribution in income generation. It has revealed that women earn less than Rs.5000 per month in the slum areas of Hyderabad. They give extensive time to their work for generating more income. On the basis of results, this study concludes that females were facing multiple problems such as illiteracy, lack of technical skills, less income and less opportunity, etc. These findings are enough for the policy makers and government to formulate policy in informal sector concern to women.
\end{abstract}

Keyword: Informal Sector, Women's Contribution, Working Hours, Technical Skills and Income, Nature of Jobs.

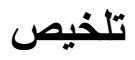

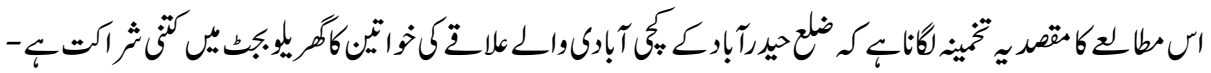

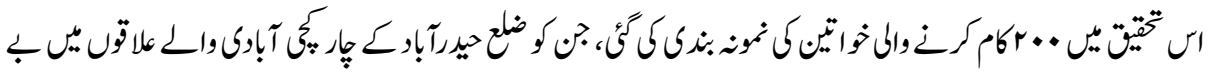

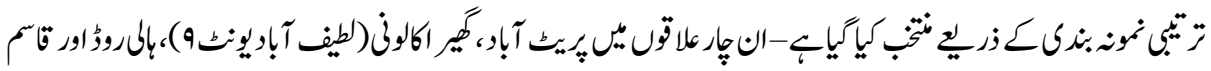

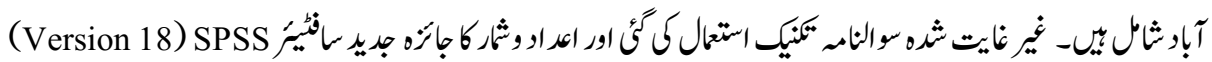

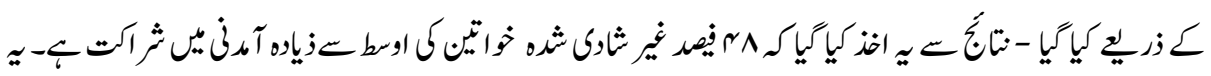

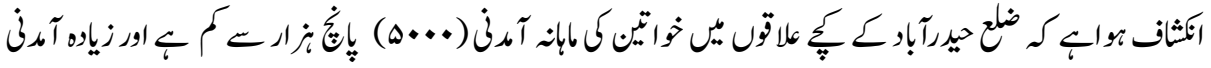




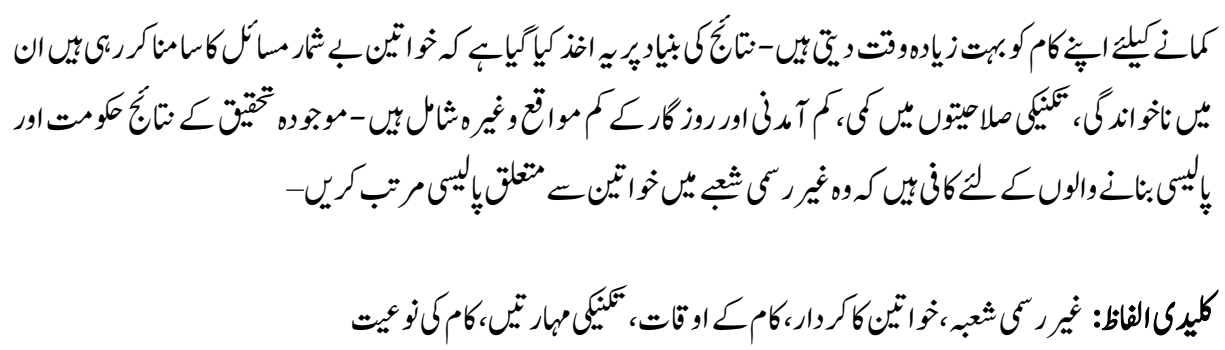

\section{Introduction}

Pakistan is a developing country where a general standard of life is not improving as it is in many other countries of Asia and Asia Pacific. Women everywhere play a constructive role in the economic development of the country. In Pakistan too, females are also playing though limited, but a proactive role in industries, factories, offices and at home businesses in Pakistan.

As far as role of women in informal sector is concerned, 'they have some disadvantages in work as compared to men. But, in Pakistan they are vulnerable and there is no easy employment available for them. There salaries are also low. 'The monthly income of more than three-fourths of employees of the informal sector is less than Rs.1,500'(Dawn, 2011). It was estimated that 'The total workforce of home-based women workers (HBWW) was approximately 12 million'. In urban areas, women strength in home-based work is 1,275,022 (41.9\%) in Punjab, 905,401 (29.8\%) in Baluchistan, 748,056 (24.6\%) in Sindh, and 111,790 (3.7\%) in Khyber Pakhtunkhwa (Dawn, 2011). To some extent, women have a significant contribution in household income generation (Khan \& Khan, 2007, 2008, 2009). Moreover, informal activities attracted the women to participate in economic activities and to support their families economically (Kazi and Sathar, 1986). Top of Form Women have 26\% sharing of earning in the total income in household in Pakistan. However, the rate of economic activities is $40 \%$ of men (MHDC, 2000). According to FBS (2003), the participation rate of female in labor force in Pakistan was just $14.4 \%$ as compared to $70.3 \%$ of male. However, the male share of the employed labor force decreased by six percent point from 2001 to 2008 and resulted in a corresponding increase in the share of the female share of the employed labor force. According to LFS (2007-8), the total employed labor force of Pakistan was 49.04 million $(95 \%)$ out of them 10.03 million (19.4\%) were female during the fiscal year 2008-9.

On account of Pakistan's Employment Trend (2013), overall, in manufacturing sector, women's excessive working hours was sharply decreased from 24.2 percent in 2008-9 to 15.4 percent in 2012-13. But, women spent excessive hours in the business of fishing, mining, construction, wholesale and retail trade, hotel and restaurant, transport and communication, health, social work and other community, social and household services. As far as women's 
working hours in Sindh province is concerned, it has increased from 13.9 percent in 20102011 to 24.9 percent in 2012-13. Overall, women have spend more working hours in the education, health sector, construction, community, social and home based services.

In this context, Food and Agriculture Organization of the United Nations (FAO, 1995) reported that in developing countries, women have low wages for the same nature of jobs as compared to men. For example, in urban areas of Ghana, women's wages are 31 percent lower than a men's wages. Women are forcibly working on low wages. Here the term 'informal sector' is referred as 'to unauthorized, unrecorded, disorganized and small scale business and usually people self employee on low wages' (Khan, 1990). Further, it can be described as: 'All household enterprises owned and operated by own-account workers, irrespective of the size of the enterprise. Enterprises, here means concerns owned and operated by employers with less than 10 workers including the owner(s) of the enterprise, the contributing family workers, the employees, whether employed on an occasional or a continuous basis or as an apprentice. The rate of employment in informal sector was increased ten percent in a decade from $63.8 \%$ in $2001-02$ to $73.3 \%$ in $2012-13$. Out of them, male $(64.1 \%$ to $73.6 \%)$ and female $(60.8 \%$ to $70.9 \%)$ rates of employment were also raised during the period (GoP, 2014).

The aim of the study is to explore the women's contribution in income generation in informal sector under the hypothesis whether this role is significant or not. However, a large number of women work in the informal sector in Sindh, which is generally not calculated while measuring gross domestic product (GDP) of the country. In slum areas of Sindh, women are playing an important role in the development of the economy, generating additional employment opportunities through the informal sector, which needs to be quantified. In major slum areas of Hyderabad, women are in some manners earning supplementary income. But, in some cases, their role is central for livelihood. These women have different duties at homes and out. Moreover, they are engaged in informal activities for earning. Some women's income depends on small entrepreneurs. As far as women's role in the informal sector is concerned, they have a higher proportion in contribution of household income. In the informal sector, the most common source of income are embroidery, glass bangles, domestic work, nut cutting, sewing clothes, beauty parlor, shop keeping and food selling in Paratabad, Ghera coloni (Latifabad Unit 9), Haliroad and Qasmabad slum areas of Hyderabad (Sindh). Hyderabad is the second larger city of Sindh after Karachi.

The present study explores that majority of women $(74 \%)$ are engaged in the aforementioned home based works. Women make substantial contribution in the economic growth of the country through informal activities. This study is significant to formulate government policies related to female employment opportunities in the informal sector. The study contains the following sections: Section 2 reviews literature. Section 3 provides research design. Section 4 contains data analysis and discussion. Conclusion and policy implication are given in section 5 . 


\section{Literature Review}

Many economists acknowledged that women represent a meaningful role in the growth of the country's economy. However, their contribution in income generation has underrated. Sharma (1989) reveals that most of women earn to feed their families. Unfortunately, they do unsuited work at low wages. He further said that the rate of women's participation in the informal sector has increased from $12.13 \%$ to $14.4 \%$ in 1971-1981. Women's participation in work had risen rapidly in some areas of India. Further, Sharma (1989) exhibited that educated women have more opportunities, where they are regarded as availing a lot of benefits.

No doubt, women spend excessive time to their work. In this regard Mumtaz \& Shaheed (1987) acknowledged that women work more than 14 to 16 hours per day. They are very responsible for providing accessories to household. Inspite of this fact, the women's role is considered as care taker of home. Although, 24 percent women are involved in the informal sector as a domestic servant (cooks, nannies, nurse maids), shopkeeper, beautician, good seller, glass bangles making, embroidery making, handicraft work and much more. So therefore, each job has different wages and prestigious. The study also explored that in urban areas women are working as a waitress in Pakistani restaurant, as a sale person in the boutique as well. It is unlike in developing countries of the East, Latin America and Africa (Mumtaz \& Shaheed 1987).

Jafri (1997) also says that the formal economy consists of all shades of taxes, measured, documented and regulated by the government. Generally, in the formal sector, women are educated and providing good services in the home and in organizations as well than informal sector. On another side, the informal sector do not document in the government record. Mostly, they are self-employed or do other small scale business. However, in this sector, most of people have less skills. Those skills are often learned by family. They do not have other skills nor have any vocational training. In spite of many challenges, they also face the issue of low wages. In slums areas, women are ready to do work in low wages. However, women work harder and harder due to poverty and they try to secure their family from malnutrition (ADB, 2000). Due to low wages women have a lower ratio of income to fulfill the basic accessories of the household.

To some extent, women's contribution in income generation and household expenses is considerable and gradually recognized by the society. Women's role in the informal sector in the slum areas of Hyderabad is largely neglected by the policy makers. Bertulfo et al. (2009) says that the issues of women's work at home are invisible in the policy of the government and statistics. The major reasons behind the informal sector are social constraints and gender biases. Consequently, daily works of women remain neglected. The work of women does not acknowledge. 


\section{Research Design}

A sample of 200 women respondents is chosen for the simple random technique. The convenient slum areas of Hyderabad district are Paratabad, Ghera coloni (at Latifabad Unit 9), Haliroad and Qasmabad. Particularly, in Ghera colony only three works are common, including; shop keeping, food selling and renew old dresses by stitching. Whereas, in Paratabad, the work of glass bangels is the most popular. The data is interpreted by using frequencies and percentage through the SPSS (version 18). According to Federal Bureau of Statistics (2003), if a woman is involved doing work such as: agricultural farming activities, cotton-picking, livestock and poultry breeding, maize and rice husking, construction work, making clothes, sewing, knitting, marketing and preparation of goods and material. Such a woman will be included in labour force. However, contribution of these women in their household's budget and GDP is still unexplored, along with determinants of their contribution.

\section{Data Analysis and Discussion}

The findings show that early age, lack of education, lack of access of information, untrained, fear of insecurity (e.g. harassment), less opportunities, restricted mobility, excessive working hours and low income in informal economy were major factors of women's vulnerability. Due to these issues, women continuously do manual labor work.

The contribution of women in informal sector has been analyzed in view of following variables.

- Marital status

- Age

- Technical skills

- Income of Women

- Source of Information

- Working hours

- Nature of jobs

Now, effects of above said variables are to be discussed. Effects of marital status, age, technical skills, income of women, source of information, working hours and nature of job on women's contribution in income generation.

About $48 \%$ of single status women have high contribution in income generation because they save money for their dowry gifts and other accessories. A single status female spend more time and energy in producing more products. So that, they could generate more income. On the other hand, 41.5percent married women are also kept busy in income generation. Meanwhile, married women have also responsibilities of child-caring and housekeeping. Although, most of (67.5\%) women are continuously busy in home based working, but, they are untrained. They have little skills of doing work because they learn from their family members or elders. (See Table 4.1) 
Table: 4.1

Contribution of women in household budget

\begin{tabular}{|c|c|c|c|}
\hline Variables & Category & Frequency & Percentage \\
\hline \multirow[t]{4}{*}{ Marital Status } & Single & 95 & 47.50 \\
\hline & Married & 83 & 41.50 \\
\hline & Divorced/Widow/Separated & 22 & 11.00 \\
\hline & Total & 200 & 200 \\
\hline \multirow[t]{5}{*}{ Age } & Below 16 & 16 & 8.0 \\
\hline & 17 to 25 & 85 & 42.50 \\
\hline & 26 to 35 & 65 & 32.50 \\
\hline & 36 to 50 and above & 34 & 17.0 \\
\hline & Total & 200 & 100.00 \\
\hline \multirow[t]{4}{*}{ Nature of Work } & Private jobs/ Public jobs & 39 & 19.50 \\
\hline & Home based Work & 135 & 67.50 \\
\hline & Others & 26 & 13.00 \\
\hline & Total & 200 & 100.00 \\
\hline
\end{tabular}

The findings further prove that an average income of women is less than Rs.5000 per month in slum areas (See Table 4.2). A similar result found in the study of Kousar (2010) that 'In urban areas $35 \%$ of the informally employed women were earning only Rs.3000 to 4000 per month.' A similar result has observed in the table 4.2 that majorities $(54.50 \%)$ of women are away from education and only 26 percent women have matriculated and intermediate qualification. It has revealed that lack of technical skills and illiteracy are main reasons of low income and low self confidence of women in informal sector (Karim, 2001).

Table: 4.2

Technical skills and income of women

\begin{tabular}{|c|c|c|c|}
\hline Variables & Categories & Frequency & Percentage \\
\hline \multirow{4}{*}{ Education } & Illiterate & 109 & 54.50 \\
\cline { 2 - 4 } & Primary & 28 & 14.00 \\
\cline { 2 - 4 } & Matriculation and & 53 & 26.00 \\
\cline { 2 - 4 } & Intermediate & 10 & 5.00 \\
\cline { 2 - 4 } & Graduates and above Total & 200 & 100.00 \\
\hline Female Monthly & Below 5000 & 94 & 47.00 \\
\cline { 2 - 4 } Income & 6000 to 10,000 & 50 & 25.00 \\
\cline { 2 - 4 } & 11,000 to 15,000 & 21 & 10.50 \\
\cline { 2 - 4 } & above 15,000 & 35 & 17.50 \\
\cline { 2 - 4 } & Total & 200 & 23.00 \\
\hline Vocational & Trained & 46 & 77.00 \\
\cline { 2 - 4 } Training & Untrained & 200 & 100.00 \\
\cline { 2 - 4 } & Total & & \\
\cline { 2 - 4 }
\end{tabular}


Generally, women's contribution in a household relates to its family size. Table 4.3 convincingly show women's participation among different family members in informal activities. Among overall respondent, 78 percent households live atleast 10 family members. It is burden on women and men too. It found that 51 percent women have less than five years working experience. This data shows that women's participation in informal work has increased in last five years. These findings are also supported by Malik and Khan (2009). Whereas, 28.50 percent women had more than 6 to 15 years work experience. Similarly, $72.50 \%$ women live in their own home. The owner of the property might be their husband/father, etc. Therefore, they do not contribute in rent charges, but in some cases 27.50 percent women have to share some amount of their income in their home rent as shown in table 4.3.

Table 4.3

\begin{tabular}{|c|c|c|c|}
\hline Variables & Categories & Frequency & Percentage \\
\hline Family Members & below 10 & 156 & 78.00 \\
\cline { 2 - 4 } & 11 to 15 and above & 44 & 22.00 \\
\cline { 2 - 4 } & Total & 200 & 2.00 \\
\hline Work Experience & below 5year & 102 & 51.00 \\
\cline { 2 - 4 } & 6 to 15 & 57 & 28.50 \\
\cline { 2 - 4 } & 16 to 20 and above & 30 & 15.00 \\
\cline { 2 - 4 } & 21 & 11 & 3.50 \\
\cline { 2 - 4 } & Not Answered Total & 200 & 100.0 \\
\hline Owner of Property & Own Assets & 145 & 72.50 \\
\cline { 2 - 4 } & On Rent & 55 & 27.50 \\
\cline { 2 - 4 } & Total & 200 & 100.0 \\
\hline
\end{tabular}

Table 4.4 indicates different sources of information available for women such as T.V, mobile, social network and internet. Among all sources of information, television is found the most popuplar among women in Hyderabad. T.V as a source of information is being used by 58.50 percent women that is followed by mobile, social network and internet sources.

Table: 4.4

Source of information

\begin{tabular}{|l|c|c|}
\hline \multicolumn{1}{|c|}{ Source of Information } & Frequency & Percentage \\
\hline T.V & 117 & 58.50 \\
\hline T.V and Mobile & 47 & 23.50 \\
\hline T.V, Mobile and Social Network & 24 & 12.00 \\
\hline T.V, Mobile, Social Network and & 12 & 6.00 \\
\hline Internet Total & 200 & 100.0 \\
\hline
\end{tabular}


Table 4.5 manifested that unmarried girls are giving (62\%) more than 5 to 9 hours to their work. Even though, they just give 2 hours as a break for lunch time and rest. After break they start their work and continue till evening in summer season. Sometimes they give more than $10 \mathrm{hrs}$ to work in winter season. Mostly, they like to give more than $10 \mathrm{hrs}$ and produce more product for more earning. They generate more income for celebration of special event, like holy days, weddings, etc. Teenage girls also save money for dowry, wedding arrangements of sibling or relatives.

Table: 4.5

Working hours

\begin{tabular}{|l|c|c|}
\hline Hours spent in generation of income & Frequency & Percentage \\
\hline 2 to $4 \mathrm{hrs}$ & 31 & $15.5 \%$ \\
\hline 5 to $9 \mathrm{hrs}$ & 124 & $62.0 \%$ \\
\hline more than $10 \mathrm{hrs}$ & 45 & $22.5 \%$ \\
\hline Total & 200 & $100 \%$ \\
\hline
\end{tabular}

The nature of work in each area (like Qasmabad, Parytabad, Haliroad and Ghyra Basti) is different. It depends on the availability of the work at home. In Parytabad, women are mostly engaged in making bangles. Women are unaware about the demand of the product at home. A middle man provides products for further work to women at home. They also agreed to work on the wages as decided by middle man. In Qasmabad, women like to do domestic work like sweeper, nanny, maid, etc. And, in Ghyira Basti, majority of women are earning income by selling cultural food. Parytabad, Qasmabad, Haliroad and Ghyra Basti are old and slum areas of Hyderabad city. This survey reveals the fact that after food selling (32.5\%), making glass Bangles' (15.5\%), Beauty-Parlour (9.5\%), Sewing dress $(9.5 \%)$, Embroidery (8\%) and nut cutting (6.0\%). (See Table 4.6 and figure 1).

Table: 4.6

Nature of jobs

\begin{tabular}{|l|c|c|}
\hline Nature of Job & Frequency & Percentage \\
\hline Embroidery & 16 & 8.0 \\
\hline Hat making & 2 & 1.0 \\
\hline Sewing dresses & 19 & 9.5 \\
\hline glass bangles & 31 & 15.5 \\
\hline Coaching at home & 6 & 3.0 \\
\hline domestic work & 30 & 1.0 \\
\hline nut cutting & 12 & 6.0 \\
\hline Beauty- parlor & 19 & 9.5 \\
\hline Selling food & 65 & 32.5 \\
\hline Total & 200 & 100.0 \\
\hline
\end{tabular}




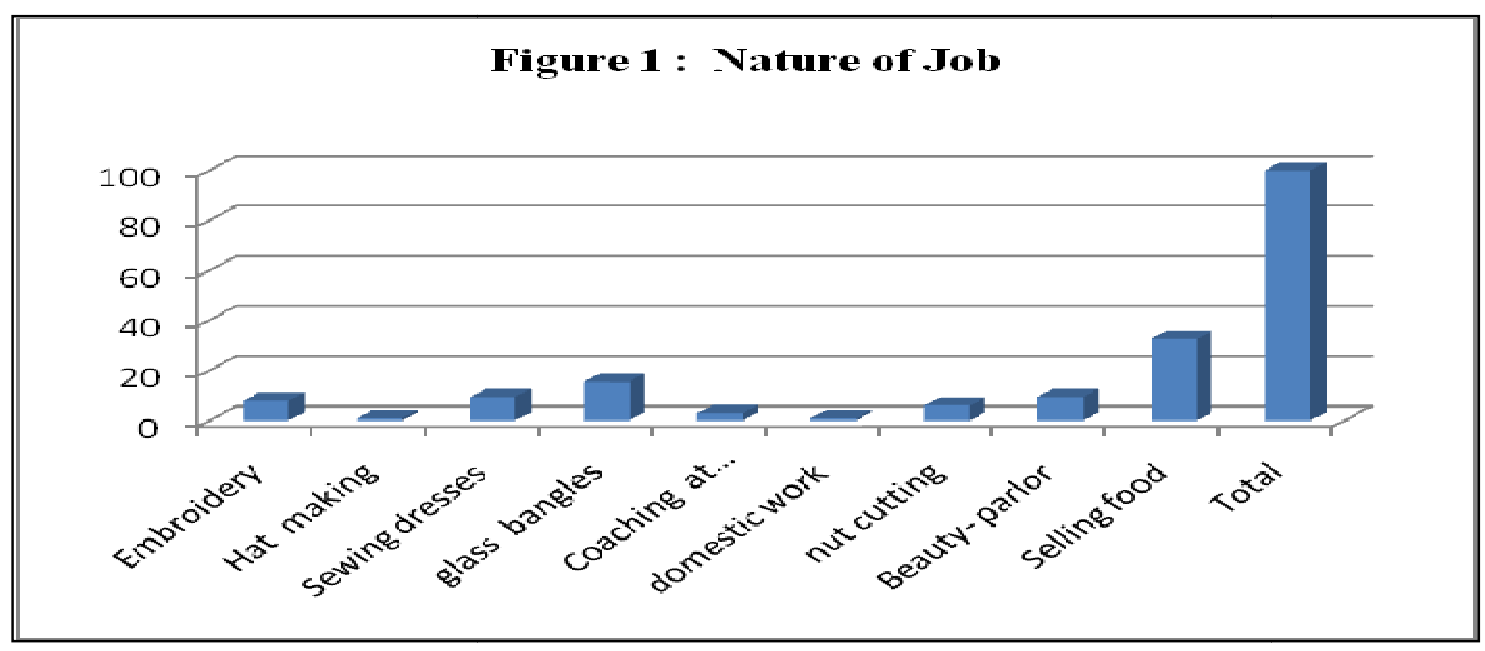

The summary of the main findings are as follows:

- Teenage girls seem to be more effective in their contribution in household budget. They have more strength for work as compared to married women. Single women spend more hours to work as compared to married women. But, married women suffer as they are home makers as well as informal workers.

- The findings further suggest that on average women earn less than Rs. 5000 per month and it is not enough, for home expenditure. It means that women are earning less than $2 \$$ in a day, which shows that according to the international standard, women in informal sector live far below the poverty line of the country (Pakistan Economic Survey, 2013-14). It may also be observed here that women are not availing the opportunities better. Girls are not allowed to do work outside of home in slum areas. Hassan and Farooq (2015) highlight a reason that is gender discrimination, due to which, females begin only home based work. These results are also in line with that of Shaheed and Mumtaz (1981). Another important shortcoming is the absence of any technical skills. Most of them are not trained for the work the undertake. Sultana and Kamal (2002) also highlight that skills, training and experience enable women to participate more in family income.

- The study has analyzed that education among women play a significant role in contribution of household income. In slum areas of Hyderabad, women avoid to go to schools. They also have not permission from head of household for getting education. Further, the progress of the public schools is not impressive.

- The large family size also has a burden on the women's income. Kouar (2010) found that 'in the nuclear families, the women working in informal sector are contributing more to their family income'.

- In slum areas of Hyderabad, women are involved in the same nature of job. They do their jobs collectively in making embroidery dresses, glass bangles, food 
selling, sewing dresses, cutting nut, services of beauty parlor and domestic work. To some extent, these results are also supported by Azid et al. (2001).

\section{Conclusions}

On the basis of results, this study concludes that women are playing pivotal role in household budget through informal activities. There are multiple problems including illiteracy, lack of technical skills and opportunities available to earn livelihood that are being faced by women enganged in informal activities. These women do not have leisure time for enjoyment. Nevertheless, women contribute substantially in family income. They have more than an average contribution in household budget and other responsibilities. In slum areas, women in informal sector are unaware of fundamental rights regarding equal wages, education and employments. Because, they have not enough access of information. These findings are enough for the policy makers and government to organize more women's development programs and awareness campaigns, particularly, to formulate policy in informal sector concern to women.

\section{References}

Asian Development Bank (ADB) (2000). Country Briefing Paper 'Women in Pakistan'. Program Department (West) and Office of Environment and Social Development.

Azid, T., Aslam, M. \& Omer, M. (2001). Poverty, Female Labor Force Participation, and Cottage Industry: A Case Study of Cloth Embroidery in Rural Multan. Pakistan Development Review, vol.40:4, pp.1105-1118.

Bertufo, L, F.Ihsan \& Lazo (2009). 'Home_Based Workers Scoping Exercise'. A Report for CIDA.

Daily Dawn. Amir, Intikhab (2011). Women's Presence in Business, $2^{\text {nd }}$ August 2011.

Daily Dawn. Staff Reporter (2011). Labour Rights for Home-Based Workers Urged, $1^{\text {st }}$ August, 2011.

Federal Bureau of Statistics (2003). Labor Force Survey, Federal Bureau of Statistics, Statistics Division, Islamabad.

Federal Bureau of Statistics (2007). Labor Force Survey, Federal Bureau of Statistics, Statistics Division, Islamabad. 
Food and Agriculture Organization of the United Nations (FAO, 1995) retrieved from: http://www.fao.org/docrep/017/v6800e/v6800e.pdf

Government of Pakistan. (2014). Economic Survey of Pakistan (2014-15). Minister of Finance. Islamabad. Retrieved from http://www.finance.gov.pk/survey_1415.html

Hassan, Syeda, Mehnaz \& Farooq, Fatima (2015). Gender Perspective of Informal Sector of the Economic in Pakistan, Pakistan Journal of Commerce and Social Sciences, vol.9:1.

Jafri, S. M. (1997). Measuring Informal Sector Employment in Pakistan. Pakistan Economic and Social Review, vol.35:2, retrieved from: http//www.jstor.org/stable/25825161. Dated 5January2015. At 1:20PM.

Karim, N. A. (2001). Jobs, Gender and Small Enterprises in Bangladesh: Factors Affecting Women Entrepreneurs in Small and Cottage Industries in Bangladesh. SEED Working Paper No. 14. ILO.

Kazi, S. \& Z. A. Sathar, (1986). Productive and Reproductive Choices: Report of a Pilot Survey of Urban Working Women in Karachi, The Pakistan Development Review, vol.25:1, pp.593-606.

Khan, R. E. A. \& Khan, T. (2007). Informally Employed Women: Their Characteristics and Contribution in Household Budget, Journal of Applied Sciences, vol.7:14, pp.1901-1907.

Khan, Shaheen (1990). An Assessment of Changes in the Employment Situation of Pakistani Women in the Informal sector. Pakistan Economic and Social Review, vol.XXULL:2.

Khan, Shazad, Farid. et.al. (2005). A Sociological Study of Working Women in Informal Sector of Readymade Garments Industry in Faisalabad; Pakistan. Journal of Agriculture \& Social Sciences, vol.1:1.

Khan, T. \& Khan, R. E. A. (2008). Household Characteristics: How much They Affect Women's Contribution in Household Budget, Indian Journal of Labor Economics.

Khan, Tasneem \& Khan, Rana, Ejaz Ali. (2009). Urban Informal Sector: How Much Women Are Struggling for Family Survival. The Pakistan Development Review (Spring). 
Kousar, Tasnim (2010). Women's Contribution of the Family Budget: Informal Labor Market in Pakistan; A Case Study of Bhawalpur District. Department of Economics, Islamic University of Bhawalpur, retrieved from: eprint.hec.gov.pk/6999/ Dated 31May 2016. At 1:30pm.

Malik, S. \& Khan, T. (2009). Family Size, Composition and Women Work in Informal Sector, Pakistan Journal of Social Sciences, vol.29:2, pp.223-233.

MHDC (2000). Human Development in South Asia: The Gender Question. Mahboob ul Haq Human Development Center, Islamabad. Oxford University Press Karachi.

Mumtaz, Khawar \& Saleem, Nadia (2010). Informal Economy Budget Analysis in Pakistan and Ravi Town, Lahore. Women in Informal Employment Globalizing and Organizing (WIEGO) Working Paper No 14.

Mumtaz, Khawar \& Shaheed, Farida (1987). Women of Pakistan: Two Steps Forward, One Step Backward'. London and Karachi: Zed.

Pakistan Economic Survey. (2013-14). Government of Pakistan, Economic Adviser's Wing, Finance Division, Islamabad.

Pakistan Economic Survey. (2014-15). Government of Pakistan, Economic Adviser's Wing, Finance Division, Islamabad.

Pakistan Employment Trend (2013). Government of Pakistan, Statistics Division, Pakistan Bureau of Statistics. Islamabad.

Shaheed, F. \& K. Mumtaz, (1981). Invisible Workers: Piecework Laborer among Women in Lahore. B. K. M. Associates Lahore and Women's Division, Government of Pakistan, Islamabad.

Sharma, U. (1989). Women's Work, Class and the Urban Household. A Study of Shimla, North India. London and NewYork: Tavistock .

Siddique, A. et al. (2009). An Assessment of Female Participation in Income Generating Activities in Agriculture Sector in Rural Areas of District Sialkot. The Jaournal of Animal \& Plant Sciences, vol.19:4.

Sultana, S. A. \& Kamal, M. A., (2002). Open and Distance Learning to Empower Rural Women in Bangladesh. 
Shazia Shahab Sheikh is Lecturer in the Department of Media \& Communication Studies, University of Sindh, Jamshoro.

Abida Hafeez is Research Scholar in the Applied Economics Research Center (AERC) University of Karachi.

Abdul Hameed Mallah is Program Manager in Women Empowerment Program, Sindh Agricultural and Forestry Workers Co-ordinating Organization (SAFWCO), Hyderabad, Pakistan. 